DEPARTAMENTO DE BIOQUfMICA E BIOFISICA

Diretor: Prof. Dr. Metry Bacila

\title{
ENSAIO SÔBRE METTODOS DE OBTENÇÃO DE MUTANTES AUXOTRÓFICOS EM XANTHOMONAS CAMPESTRIS *
}

\author{
(ASSAYS ON EXPERIMENTAL METHODS FOR THE OBTENTION OF \\ AUXOTROPHIC MUTANTS FROM XANTHOMONAS CAMPESTRIS)
}

MaRia Helen A Juliani **

Sérgio Olavo Pinto da Costa

Prof. Assistente Doutor

\section{INTRODUÇÃO}

Mutantes auxotróficos são largamente usados em pesquisa genética e bioquímica. A expressão, mutantes bioquímicos, aplica-se a mutantes que perderam ou ganharam um requerimento nutricional, ou ainda, apresentaram modificações em processos metabólicos, tais como fermentação, por exemplo. Os mais estudados dentre os mutantes bioquímicos são os mutantes auxotróficos, os quais necessitam de um fator de crescimento não necessário ao crescimento das células não mutadas, também chamadas de selvagens ou prototróficas.

Um dos métodos mais eficientes desenvolvidos para o isolamento de mutantes bioquímicos foi o "método da penicilina", descoberto simultâneamente por LEDERBERG e ZINDER (1948) e DAVIS (1948). Êsse método é aplicável a tôdas as espécies de bactérias sensiveis à penicilina e baseia-se no fato de que essa droga é um antibiótico que mata ràpidamente células em crescimento, mas é inócuo para aquelas que não se reproduzem. Quando uma mistura de bactérias prototróficas e auxotróficas é lavada para remover o material nutritivo e é, então, incubada em meio mínimo, contendo concentrações bactericidas da penicilina, muitos dos prototróficos morrem, pois se dividem nesse meio, enquanto que os mutantes presentes não crescem por se tratar de meio deficiente e, portanto, sobrevivem a despeito da presença da penicilina.

* Trabalho realizado com auxilio da Coordenação de Aperfeiçoamento de Pessoal do Ensino Superior (CAPES) e do Projeto FUNTEC N.o 31, do Banco Nacional do Desenvolvimento Econômico.

* Bolsista da CAPES. 
Certas modificações que aumentam a eficiência do método da penicilina foram desenvolvidas. Uma delas (GoRINI e KAUFMAN, 1960) utiliza período relativamente curto de exposição à droga e meio mínimo hipertônico contendo sacarose 0,54 M para impedir a lise dos prototróficos e consequente "cross feeding" dos auxotróficos. Em outro método (AdelBerg e Myers, 1953), o processo todo é feito em meio sólido ao invés de meio líquido; a vantagem dêsse método é que, enquanto no método de cultivo em meio líquido vários dos auxotróficos fenotipicamente idênticos podem ter se originado de uma célula mutante original, aqui cada colônia auxotrófica corresponde a um evento mutacional. LUBIN (1962) empregou o método geral de seleção pela penicilina, mas usou vários ciclos de tratamento com a droga.

O método da penicilina, além de servir para o isolamento de diferentes classes de mutantes, também serve para o isolamento de classes específicas; para isto basta adicionar ao meio mínimo com penicilina fatôres de crescimento específicos, que promovem o crescimento de mutantes não desejados, dêsse modo eliminando-os com os prototróficos, ou então adicionar o fator de crescimento desejado no estágio de pós-irradiação, em que apenas o tipo desejado de mutante auxotrófico crescerá junto com a população normal. Do mesmo modo, duplos auxotróficos, tendo dois requerimentos, podem ser obtidos, partindo-se de uma linhagem que já requer um fator de crescimento. Por outro lado, certos tipos de mutantes, como por exemplo os requerendo timina, são extremamente difíceis de isolar pela técnica da penicilina, devido à inabilidade do mutante "thymineless" (thy ${ }^{-}$) em sobreviver em um meio sem timina. Contudo, um procedimento para seu isolamento foi descoberto através da utilização da sobrevivência de mutante thyem meio contendo altas concentrações de aminopterina e timidina (BRAUN, 1966).

Outro método emprega os efeitos letais da timidina $-\mathrm{H}^{3}$ que em meio mínimo é incorporada ao DNA das células em multiplicação (prototróficas) mais ràpidamente do que no DNA de células não em multiplicação (auxotróficas); assim, os auxotróficos são mortos em velocidade mais baixa durante ulterior estocagem a $5^{\circ} \mathrm{C}$ por 6 a 13 dias (LuBIN, 1959).

O princípio de "suicídio seletivo de prototróficos" tem sido usado em procedimentos em que o prototrófico paternal é dependente de ácido diaminopimélico $\left(\mathrm{DAP}^{-}\right)$ou de timina (thy ${ }^{-}$); assim, os paternais morrem quando cultivados em meio sem DAP ou timina, em virtude de requererem DAP para sintese de parede celular ou timina (BAUMAN e Davis, 1957).

No caso de bactérias formadoras de esporos pode-se fazer um tratamento com aquecimento, já que esporos e células vegetativas mostram diferente sensibilidade à temperatura. Nêsse caso, prototróficos em germinação são mortos em meio mínimo, enquanto 
que esporos não germinando sobrevivem e podem voltar a germinar em meio enriquecido (IYER, 1960).

Além da penicilina, a estreptomicina (IsHIDA et al., 1966), 5-fluorouracil (WACHSMAN e HoGG, 1964), 8-azaguanina (WACHSMAN e MANGaLo, 1962) têm sido utilizadas na seleção dêsses mutantes. No caso da 8-azaguanina, a droga é utilizada por ser bactericida, para cẻlulas em multiplicação. Com isso ela é, então, empregada para isolar mutantes auxotróficos de linhagens que lhe são susceptíveis, incluindo aquelas em que o método da penicilina não é aplicável, devido à produção de penicilinase pelas células.

Tôdas as técnicas indicadas utilizam a luz ultravioleta como mutagênico. Recentemente um novo mutagênico químico, o $\mathrm{N}$-metil, N-nitrosoguanidina, tem sido utilizado na obtenção de mutantes (ADELBERG et al., 1965).

Xanthomonas campestris é uma bactéria fitopatogênica que ataca as crucíferas produzindo a conhecida podridão negra. Foi demonstrado (CosTA, 1967), que esta bactẻria sofre transformação genética medida por DNA levando duas marcas a resistência a drogas (estreptomicina e eritromicina). O interêsse agora é verificar que outros fenômenos de recombinação genética podem ocorrer. Para isso, há necessidade de obtenção de várias linhagens poliauxotróficas da referida bactéria.

$O$ objetivo dêste trabalho foi o de determinar os métodos de obtenção de mutantes auxotróficos mais adequados para Xanthomonas campestris.

\section{MATERIAL E MÉTODOS}

Linhagens utilizadas. Xanthomonas campestris, linhagens auxotróficas requerendo glicina $\left(\mathrm{gly}^{-}\right)$e histidina (his ${ }^{-}$) obtidas do tipo selvagem da coleção dêste laboratório. Linhagens números 1 e 17 de $X$. campestris isoladas e identificadas a partir de caule de couve (Brassica oleracea, var. acephala).

Meios de cultura. Para cultivo em meio mínimo utilizou-se o meio de Starr (1946) : glicose, 0,5 g; $\mathrm{NH}_{1} \mathrm{Cl}, 0,1 \mathrm{~g} ; \mathrm{KH}_{2} \mathrm{PO}_{1}, 0,2 \mathrm{~g}$; $\mathrm{MgSO}_{4} .7 \mathrm{H}_{2} \mathrm{O}, 0,02 \mathrm{~g} ; \mathrm{H}_{3} \mathrm{BO}_{3}, 0,5 \mu \mathrm{g} ; \mathrm{CaCO}_{3}, 10 \mu \mathrm{g} ; \mathrm{CuSO}_{4} .5 \mathrm{H}_{2} \mathrm{O}$, $1,0 \mu \mathrm{g} ; \mathrm{FeSO}_{4}\left(\mathrm{NH}_{4}\right)_{2} \mathrm{SO}_{4} 6 \mathrm{H}_{2} \mathrm{O}, 10,0$ ou $50,0 \mu \mathrm{g} ; \mathrm{KI}, 0,1 \mu \mathrm{g} ; \mathrm{MnSO}_{4}$. $\mathrm{H}_{2} \mathrm{O}, 1,0$ ou $2,0 \mu \mathrm{g} ; \mathrm{MoO}_{3}, 10 \mu \mathrm{g} ; \mathrm{ZnSO}_{1}$. $7 \mathrm{H}_{2} \mathrm{O}, 5,0 \mu \mathrm{g}$; ácido glutâmico (DL) 0,1 g; metionina (DL), 0,02 g; água destilada, $100 \mathrm{ml}$; $\mathrm{pH}$ final 6,8, sendo que para o meio mínimo sólido, os sais, a glicose e o agar foram autoclavados separadamente e misturados depois de resfriamento. Culturas estoques foram mantidas em agar inclinado nutritivo. O meio sólido utilizado foi o agar nutritivo, contendo peptona ( $5 \mathrm{~g}$ ), extrato de carne (3 g) e agar (15 g) dissolvidos $\mathrm{em} 1000 \mathrm{ml}$ de água destilada.

Drogas. Penicilina G. potássica, com potência equivalente a 1509 unidades/g; as soluções foram sempre preparadas momentos 
antes de serem utilizadas. Os amino ácidos foram usados na concentração final de $3-10 \mu \mathrm{g} / \mathrm{ml}$, exceto para cistina e treonina que foram utilizados respectivamente na concentração de $50 \mu \mathrm{g} / \mathrm{ml}$ e $30 \mu \mathrm{g} / \mathrm{ml}$. A preparação de ácidos nucléicos de levedura (Roper, 1963) foi feita colocando-se $2 \mathrm{~g}$ de ácido nucléico de levedura em $15 \mathrm{ml}$ de solução normal de $\mathrm{NaOH}$ e $2 \mathrm{~g}$ em $15 \mathrm{ml}$ de solução normal de $\mathrm{HC1}$; as duas soluções foram aquecidas a $100^{\circ} \mathrm{C}$ por $20 \mathrm{mi}$ nutos, misturadas, ajustado o $\mathrm{pH}$ para 7,0 e filtradas a quente; o volume foi ajustado a $40 \mathrm{ml}$ e a solução foi guardada no escuro sob clorofórmio.

A penicilina $G$ potássica foi fornecida pela Squibb Indústria Química S A; sais minerais e amino ácidos eram 1odos pru-análisse. Os constituintes dos meios nutritivos e o extrato de levedura procederam da Oxoid.

Ação da penicilina sôbre Xantromonas campestris cultivada em meio mínimo. Bactérias da linhagem n." 17 cultivadas por 30-48 horas em caldo nutritivo foram centrifugadas, lavadas uma vez com meio mínimo e aproximadamente 1,5 do sedimento foi inoculado em meio mínimo. Depois de incubação a $28 \mathrm{C}$ por $14-17$ horas, quando o número de bactérias duplicou, penicilina foi adicionada ao frasco na concentração final de 2000 unidades $\mathrm{ml}$. A cultura foi incubada a $28^{\circ} \mathrm{C}$, sendo que em alguns experimentos ela foi submetida à agitação em agitador rotatório $(190 \mathrm{rpm}) \mathrm{e} \mathrm{em}$ outros à aeração por borbulhamento e amostras foram retiradas em intervalos de tempo apropriados (0,4, 8 e 12 horas), diluídas convenientemente e espalhadas com alça de Drigalsky em placas contendo agar nutritivo. Foi feito êsse processo de agitação ou borbulhamento de ar para propiciar melhor condição de desenvolvimento e, consequentemente, melhores possibilidades de ação da droga, pois esta bactéria apresenta um crescimento lento em meio mínimo.

Obtenção de mutantes auxotróficos. Vários métodos foram utilizados, sendo que inicialmente foi empregado o processo simplificado pelo uso apenas de irradiação por luz ultravioleta (método $a)$ :

Mutante de Xanthomonas campestris da linhagem n." 1 com a marca glicina (gly-) foi semeado em $15 \mathrm{ml}$ de caldo nutritivo e incubado por 48 horas a $28^{\circ} \mathrm{C}$. A seguir foi centrifugado a 7000 rpm durante 5 minutos e o sedimento foi suspenso no mesmo volume de meio mínimo. Após, $5 \mathrm{ml}$ desta suspensão foram colocados em uma placa de petri protegida com papel alumínio a fim de se evitar fotoreativação por luz incidente e irradiados durante 100 segundos por luz ultravioleta (Sterillamp, 15 watts, comprimento de onda curta, 2537 Á). O material irradiado foi colocado em um 1ubo com $15 \mathrm{ml}$ de caldo nutritivo e a cultura ficou no escuro para que desse algumas gerações a fim de prevenir a fotoreativação. Incubou-se por 24 horas a $28^{\circ} \mathrm{C}$; diluições apropriadas da cultura 
foram feitas e $1 / 10$ de cada diluição foi colocado em placas contendo agar nutritivo. Decorridas 48 horas, as melhores placas (30 a 300 colônias) foram replicadas, respectivamente, em placas contendo meio mínimo adicionado de glicina na concentração final de $6 \mu \mathrm{g} \mathrm{ml}$ e meio completo, utilizando-se a técnica da réplica de LEDERBERG \& LEDERBERG (1952). As bactérias que cresceram no agar nutritivo e não o fizeram no meio mínimo adicionado de glicina, eram provàvelmente duplo mutantes e foram a seguir isoladas e mantidas em agar inclinado. Posteriormente foram retestadas para confirmação. Esta mesma técnica foi utilizada partindo-se de um mutante deficiente para a sintese de histidina (his ${ }^{-}$).

Posteriormente foi utilizado o método $b$, baseado no de GoRINI e KaUfMan (1960), que consistiu do seguinte: Xanthomonas campestris de linhagem selvagem $n .{ }^{\circ} 17$ foi cultivada em meio mínimo por 48 horas a $28^{\prime} \mathrm{C}$. $5 \mathrm{ml}$ dessa cultura foram irradiados durante 100 segundos pela luz ultravioleta, de modo a haver $99,99 \%$ de morte (redução de $8 \times 10^{7}$ células $/ \mathrm{ml}$ para $4 \times 10^{3}$ céculas $/ \mathrm{ml}$ ). O material irradiado foi transferido para frasco contendo $40 \mathrm{ml}$ de meio mínimo adicionado com aminoácido (fenilalanina ou isoleucina e valina, $10 \mathrm{~g} \mathrm{ml}$ ); para se impedir a fotoreativação por luz incidente, o frasco foi mantido no escuro por, pelo menos, 24 horas. Depois de incubação por 48 horas, a $28^{\circ} \mathrm{C}$, a cultura foi centrifugada e lavada uma vez com meio mínimo. Aproximadamente $1 / 5$ do sedimento $\left(4 \times 10^{9}\right.$ células $)$ foi inoculado $\mathrm{em} 40 \mathrm{ml}$ de meio mínimo contendo sacarose 0,54 M e MgSO, 0,01 M. A cultura permaneceu por doze horas a $28^{\circ} \mathrm{C}$, de modo que a população aproximadamente dobrasse, ou seja, as células entrassem na fase exponencial. Penicilina, foi então adicionada em uma concentração final de 2000 unidades $\mathrm{ml}$. O frasco foi incubado a $28^{\circ} \mathrm{C}$, mantido em agitação, por 8 horas (a sobrevivência foi de aproximadamente $0,1 \%$ ) e as células foram lavadas uma vez para se impedir a ação da penicilina residual. O sedimento foi suspenso no mesmo volume, em meio mínimo e diluições apropriadas foram plaqueadas em agar nutritivo. A seguir, as melhores placas (30-300 colônias) foram replicadas, respectivamente, em placas contendo agar nutritivo e meio mínimo, pela técnica da réplica, de LeDerBerg e LEDERBERG (1952). As colônias que cresceram no agar nutritivo e não o fizeram no meio mínimo foram selecionadas e a seguir testadas em meio mínimo líquido para confirmar a sua condição de mutantes.

Após foi feita uma modificação (método $c$ ) nesta última técnica, utilizando-se o método de LUBIN (1962), onde $9 \mathrm{ml}$ de uma cultura de $X$. campestris da linhagem n. ${ }^{\circ} 17$ cultivada até fase exponencial em meio mínimo (7. $10^{\text {a }} 10^{\circ}$ células $/ \mathrm{ml}$ ) foram expostos a uma dose de irradiação por luz ultravioleta, durante 100 segundos, o que reduziu o número de células viáveis de aproximadamente $10^{8}$ a $10^{*}$ células $/ \mathrm{ml}$. A amostra irradiada foi inoculada em 
$40 \mathrm{ml}$ de meio mínimo contendo triptofano, treonina, serina, lisina, fenilalanina, valina, cisteína, prolina, isoleucina e valina $(6 \mu \mathrm{g} / \mathrm{ml})$. Depois de 48 horas de incubação a $28^{\circ} \mathrm{C}$, a cultura foi centrifugada a $0^{\circ} \mathrm{C}$ e lavada uma vez com meio mínimo. Aproximadamente $1 / 5$ do sedimento foi inoculado em $40 \mathrm{ml}$ de meio mínimo contendo sacarose $0,54 \mathrm{M}$ e $\mathrm{MgSO}_{1}$ 0,01 $\mathrm{M}$. A cultura permaneceu a $28^{\circ} \mathrm{C}$ por 14-17 horas até que o número de células atingisse o dôbro, quando então, penicilina foi adicionada na concentração final de 2.000 unidades $/ \mathrm{ml}$. O frasco foi incubado, mantido em agitação, por 8 horas, a $28^{\circ} \mathrm{C}$, as células foram lavadas e transferidas novamente para um frasco contendo meio mínimo e aquéles mesmos amino ácidos. Depois de 48 horas de incubação a cultura foi centrifugada, lavada uma vez e novamente repetiu-se o tratamento com penicilina.

Ensaios de caracterização de mutantes. Cada colônia isolada pelos métodos acima referidos, que não conseguiu desenvolver-se em meio mínimo, foi a seguir testada para se descobrir qual era o fator de crescimento necessário para o seu crescimento. Uma triagem inicial foi feita, verificando-se o crescimento das colônias e meio mínimo líquido adicionado de caseína hidrolisada, extrato de leveduras e hidrolisado de ácidos nucléicos de levedura. A caseína hidrolisada é fonte de amino ácidos, ainda que vitaminas possam também estar presentes; o extrato de leveduras supre uma variedade de fatôres, incluindo purinas, pirimidinas, amino ácidos, peptídeos e vitaminas; o hidrolisado de ácidos nucléicos é fonte de mononucleotídeos e nucleosídeos que satisfazem as deficiências de muitas linhagens que requerem purinas ou pirimidinas. Assim sendo, pode-se ter uma idéia mais ou menos aproximada da deficiência de um mutante. Depois, para se conhecer a deficiência exata do mutante, usou-se o método de TAKAHASHI (1959) ou o método auxanográfico de BEIJERINCK (BRAUN, 1966), ambos utilizando meio sólido, ou então testou-se diretamente em meio mínimo líquido adicionado de fatôres de crescimento.

\section{RESULTADOS}

Ação da penicilina sôbre Xanthomonas campestris cultivada em meio mínimo. De acôrdo com a Tabela $I$, nota-se que a agitação da cultura durante a incubação com penicilina é muito importante, pois a percentagem de sobrevivência foi bem menor do que com aeração da cultura. Com 8 horas a ação da droga já é bem eficaz.

Obtenção de mutantes auxotróficos. No método $a$, de 13 colônias que não haviam inicialmente crescido em placas contendo meio minimo adicionado de glicina, apenas uma (n. ${ }^{\circ} 90$ ) continuou não crescendo nesse meio depois de três testes sucessivos em que se empregou meio mínimo líquido ou sỏlido. Quando se partiu 
de um mutante que requeria histidina, de 4 colônias inicialmente isoladas por não terem crescido em meio mínimo adicionado de histidina, apenas duas ( . $^{\circ} 56$ e 71) confirmaram posteriormente serem incapazes de crescimento em meio mínimo adicionado de histidina.

TABELA $I$ - Ação da penicilina sôbre $X$. campestris cultivada em meio mínimo* * Média de 3 experimentos.

\begin{tabular}{|c|c|c|c|c|c|c|}
\hline & \multicolumn{3}{|c|}{ Com agitação } & \multicolumn{3}{|c|}{ Com aeracão } \\
\hline $\begin{array}{l}\text { Horas após adi- } \\
\text { ção da penici- } \\
\text { lina }\end{array}$ & $\begin{array}{r}\text { Células } \\
\mathrm{ml}\end{array}$ & por & $\begin{array}{c}\text { Sobrevivência } \\
(\%)\end{array}$ & $\begin{array}{r}\text { Células } \\
\mathrm{ml}\end{array}$ & por & $\begin{array}{c}\text { Sobrevivência } \\
(\%)\end{array}$ \\
\hline 0 & $3,2 \times$ & $10^{8}$ & 100 & $3,2 \times$ & $10^{8}$ & 100 \\
\hline 4 & $5,9 \times$ & $10^{6}$ & 1,84 & $1,3 \times$ & $10^{7}$ & 4,38 \\
\hline 8 & $5,1 \times$ & $10^{=}$ & 0,16 & $8,5 \times$ & $10^{6}$ & 2,66 \\
\hline 12 & $4,8 \times$ & $10^{5}$ & 0,15 & $1,7 \times$ & $10^{\circ}$ & 0,53 \\
\hline
\end{tabular}

Bactérias cultivadas por 30-48 horas foram lavadas e $1 / 5$ do sedimento fol inoculado em meio minimo. Quando a cultura atingiu a fase exponencial penicilina (2.000 unidades $/ \mathrm{ml}$ ) foi adicionada ao frasco. Foi feita incubação a $28^{\circ}$, sendo que em alguns experimentos fêz-se agitação da cultura e em outros aeração e amostras foram retiradas em intervalos de tempo apropriados $(0,4,8,12$ horas) diluidas convenientemente e espalhadas em agar nutritivo.

No método $b$ em experimento em que foi utilizada a fenilalanina, foram examinadas aproximadamente 3000 colônias (comparação entre crescimento em placas contendo agar nutritivo e em placas com meio mínimo) e apenas 13 colônias não apresentaram crescimento em meio mínimo, tendo crescido, porém, em agar nutritivo. No entanto, quando testadas novamente, notou-se que haviam voltado à condição de prototróficas, apresentando crescimento em meio mínimo. Em outro experimento, em que foram utilizadas isoleucina e valina, foram examinadas do mesmo modo aproximadamente 2500 colônias e encontrou-se apenas uma (n. ${ }^{\circ} 33$ ) que, após testes sucessivos, confirmou a sua deficiência para crescer em meio mínimo.

Quando se utilizou o método $c$, depois do segundo ciclo de ação da penicilina, de aproximadamente 3000 colônias examinadas, 49 não apresentaram crescimento em meio mínimo, sendo que retestadas sucessivamente em meio mínimo e meio nutritivo, líquidos ou sólidos, 10 (números $1,5,15,22,24,28,11,38,41,44$ ) confirmaram ser mutantes, pois eram incapazes de crescer em meio mínimo liquido ou sólido. Das colônias restantes, 33 apresentaram crescimento residual em meio mínimo adicionado de agar purificado. Depois do primeiro ciclo de ação da penicilina, de aproxi- 
madamente 1000 colônias examinadas, 4 não apresentavam crescimento em placas com meio mínimo, sendo que retestadas novamente em meio mínimo líquido e sólido, apenas uma (n. ${ }^{\circ}$ ) confirmou não ser capaz de crescer em meio mínimo.

Ensaios de caracterização de mutantes auxotróficos. A linhagem n. ${ }^{\circ} 90$ (Tabela II), isolada pelo método $a$, apresentou crescimento quando em presença de glicina e lisina ou glicina e ornitina ou glicina e citrulina e estranhamente não foi capaz de crescer em meio contendo glicina e arginina, mesmo quando em diferentes concentraçōes.

TABELA II - Crescimento de $X$. campestris, linhagem n.o 90, em meios contendo direrentes amino ácidos

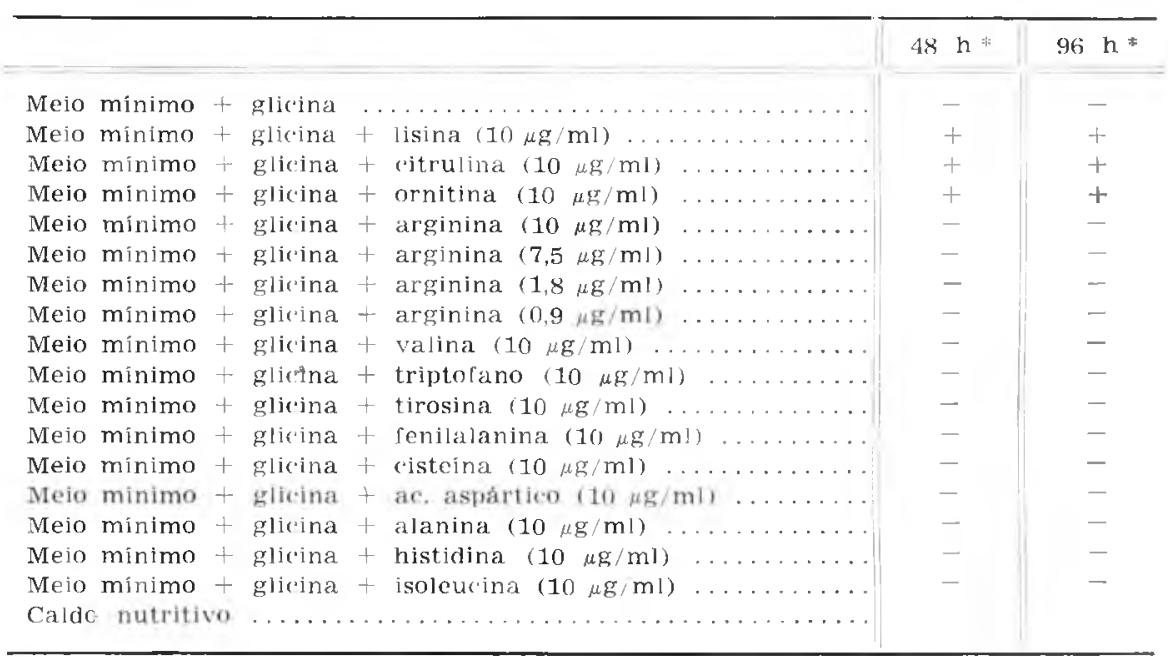

Experimentos feitos em triplicata.

$4 *+=$ crescimento; $-=$ ausên $* i a$ de crescimento.

Suspensão de células $(0,1 \mathrm{ml})$ em salina, proveniente de cultura desenvolvida por 48 horas a $28^{\circ}$, semeada em meio mínimo adicionado com diferentes amino ácidos e em caldo nutritivo (controle). As leituras dos resultalos foram reitas após 48 e 96 horas de incubacão a $28^{\circ}$.

A linhagem n. 71 isolada pelo mesmo método, de acôrdo com a técnica de triagem de TAKAHASH (1959), mostrou ser deficiente para a sintese de histidina e leucina, enquanto que a linhagem n. ${ }^{\circ}$ 51 não pôde ter caracterizada a sua deficiência pelos métodos usuais.

Com o método $b$ isolou-se uma linhagem (n." 33) que mostrou ser defíciente para a síntese de isoleucina e valina, pois só cresceu em meio mínimo, líquido, quando adicionado dêstes dois amino ácidos. 
No método $c$, de acôrdo com a Tabela III, conseguiu-se isolar 7 mutantes que necessitam de prolina para crescimento, 2 que necessitam de triptofano e 1 que necessita de isoleucina e valina. Isto foi confirmado usando-se também meio mínimo líquido.

TABELA III - Crescimento de diferentes mutantes de $X$. campestris em placas contendo diferentes amino ácidos

\begin{tabular}{c|c|l}
\hline N.o dos mutante & $\begin{array}{r}\text { Crescimento nas } \\
\text { placas }\end{array}$ & \multicolumn{1}{|c}{$\begin{array}{c}\text { Substancia } \\
\text { requerida }\end{array}$} \\
\hline 1 & C e D & Prolina \\
5 & C e D & Prolina \\
15 & A & Triptofano \\
22 & C e D & Prolina \\
24 & C e D & Triptofana \\
28 & A & Prolina \\
11 & C e D & Prolina \\
38 & C e D & Prolina \\
41 & C e D & Isoleucina + Valina \\
44 & B e D & Fenilalanina \\
3 &
\end{tabular}

Placas contendo diferentes combinacōes de fatôres de crescimento, de acôrdo com a técnica de TAKAHASHI (1959).

Utilizando a técnica de réplica, os mutantes acima foram replicados em placas com meio mínimo contendo os seguintes suplementos: placa A - - triptofano, treonina, serina, lisina; placa B - valina, treonina, isoleucina, fenilalanina; placa C cisteína, serina, isoleucina, prolina; placa D - leucina, lisina, fenilalanina, prolina. A verificacão de crescimento nas placas foi feita após 72 horas de incubacão a $28^{\circ}$. Foram testados mutantes $(1,5,15,22,24,28,11,38,41,44)$ provenientes do segundo ciclo de ação da penicilina e o mutante n.o 3 proveniente do primeiro ciclo do método $c$.

\section{DISCUSSÃO}

Com respeito à ação seletiva da penicilina, os métodos referidos na literatura, mesmo os que utilizam cultura por agitação, não chegaram a avaliar diferença entre aerar ou não a cultura. Xanthomonas campestris não tinha ainda sido submetida a ensaios desta natureza. Provàvelmente, o processo de agitação favoreceu em muito as condições de crescimento, facilitando a ação da penicilina. É possivel que a aeração do meio proporcione melhores condições para os processos oxidativos e, consequentemente, maior metabolização celular. Assim, de acôrdo com os resultados ora obtidos, parece que a agitação da cultura proporcionou melhores condições de aeração do que o processo por borbulhamento de ar. E'm adição, a agitação pode também ter permitido melhor contato das células com o meio adicionado da droga. 
O achado do método $a$ em que muitos mutantes (12), isolados inicialmente, voltaram à condição de prototróficos, não constitui fato nôvo em obtenção de mutantes; a mesma observação foi feita quando se usou o método $b$. LeDERBerg e ZiNDER (1948) constataram em Salmonella que apenas $2 / 3$ dos mutantes eram estáveis depois de repicagens sucessivas e usaram a denominação de mutantes instáveis para êsse grupo de células. Uma possibilidade é de pertencerem êsses mutantes ao sistema epissomo-controlador, referido por DAWSON \& SMITH-KEARY (1963) e SMITH-KEARY e Dawson (1964), onde êsse elemento genético bloquearia a ação de genes, ocasionando o aparecimento de "pseudo-prototróficos".

No método $c$ as 33 colônias que apresentaram crescimento residual em meio mínimo adicionado de agar purificado podem constituir mutantes que apresentam bloqueio incompleto, denominados "leaky" (CRICK al., 1961). isto é, falham em bloquear inteiramente a atividade de um gene, apresentando modificações genéticas que produzem deficiência qualitativa ou quantitativa de uma determinada enzima e o fator requerido é produzido em nível menor do que o necessário para manter crescimento normal.

Um tipo curioso de mutante foi obtido com o método $a$. Trata-se do mutante $n .^{\circ} 90$ que era deficiente para a sintese da glicina e recebeu uma marca adicional para deficiência na síntese da lisina. O crescimento em meio mínimo adicionado de ornitina ou citrulina, mas não em arginina, cria novo problema para relacionamento bioquimico da lisina com ornitina e citrulina, fato que está sendo investigado no momento.

Analisando os vários métodos ensaiados na obtenção de mutantes em Xanthomonas campestris verifica-se que o método simplificado $\alpha$ inicialmente usado, não apresenta rendimento satisfatório. O método $b$, de GoRINI e KaUfMaN (1960), apesar de ser comprovadamente eficiente na obtenção de mutantes em $E$. coli, não demonstrou eficiência nos ensaios do presente trabalho. $O$ método que se mostrou mais indicado para $X$. campestris foi uma combinação (método $c$ ) do método de GoRINI e KaUfMaN (1960) com o tratamento pela penicilina em 2 ciclos, conforme técnica preconizada por LuBIN (1962).

\section{SUMMARY}

Different methods were tried with the aim of obtaining auxotrophic mutants from the phytopathogenic bacteria Xanthomonas campestris, isolated from Brassica oleracea. The most effective method was by combining the method of GorINI and KAUFMAN, 
(using 0,54 M sucrose to avoid the lysis of prototrophic bacteria) and the method of LUBIN (by recycling the growing of the bacterial cells with penicillin. Three types of mutants were produced: a) a group of unstable mutants; b) a group of mutants with residual growth; c) a group of auxotrophic mutants requiring one of the following aminoacids: proline, tryptophane, and phenylalanine; one mutant requiring isoleucine plus valine; one mutant requiring histidine and leucine; and one mutant requiring glycine and lysine. The mutant deficient for the synthesis of glycine and lysine showed a relationship toward ornithine and citrulline, since lysine could be substituted by either one of the latter aminoacids.

\section{REFERÊNCIAS BIBLIOGRÁFICAS}

1. ADELBERG, E. A. \& MYERS, J. W. - Modification of the penicillin technique for the selection of auxotrophic bacteria. J. Bact. $65: 348-53$, 1953.

2. ADELBERG, E. A.; MANDEL, M. \& CHEN, G. C. C. - Optimal condition for mutagenesis by $\mathrm{N}$-methyl-N'-nitro-N-nitrosoguanidine in Escherichia coli K-12. Biochem. Biophys. Res. Commun. 18:788-95, 1965.

3. BAUMAN, N. \& DAVIS, B. D. - Selection of auxotrophic bacterial mutans through diaminopimelic acid or thymine deprival. Science 126: $170,1957$.

4. BRAUN, W. - Bacterial genetics. 2nd ed. Philadelphia, W. B. Saunders, 1966.

5. COSTA, S. O. P. - Transferência por transformação genética da resistência à estreptomicina e à eritromicina em Xanthomonas campestris. Trabalho apresentado para concorrer ao titulo de Mestre. Fac. Med. Vet. U.S.P., 1967.

6. CRICK, F. H. C.; BARNETT, L.; BRENNER, S. \& WATTS-TOBIN, R. J. - General nature of the genetic code for proteins. Nature, London, $192: 1227-32,1961$

7. DAVIS, B. D. - Isolation of biochemically deficient mutants of bacteria by penicillin. J. Amer. Chem. Soc. $70: 4267,1948$

8. DAWSON, G. W. P. \& SMITH-KEARY, P. F. - Episomic control of mutation in Salmonella typhimurium. Heredity, 18:1, 1963.

9. GORINI, L. \& KAUFMAN, H. - Selecting bacterial mutants by the penicilin method. Science, 131:604-605, 1960.

10. ISHIDA, T.; SETO, S. \& OSAWA, T. - Use of dihydrostreptomycin for the isolation of auxotrophic mutants of Pseudomonas aeruginosa. J. Bact. $91: 1387,1966$.

11. IYER, V. - Concentration and isolation of auxotrophic mutants of sporeforming bacteria. J. Bact. $79: 309-10,1960$. 
12. LEDERBERG, J. \& LEDERBERG, E. M. - Replica plating and indirect selection of bacterial mutants. J. Bact. $63: 399-40,1952$.

13. LEDERBERG, J. \& ZINDER, N. - Concentration of biochemical mutants of bacteria with penicilin. J. Amer. Chem. Soc. $70: 4267,1948$.

14. LUBIN, M. - Selection of auxotrophic bacterial mutants by tritium labeled thymidine. Science 129:838-9, 1959.

15. LUBIN, M. - Enrichment of auxotrophic mutant populations by recycling. J. Bact. 83:696, 1962.

16. ROPER, J. A. - Comunicação pessoal, 1963.

17. STARR, M. P. - The nutrition of phytopatogenic bacteria. I. Minimal nutritive requeriments of genus Xanthomonas. J. Bact. 51:13143, 1946.

18. SMITH-KEARY, P. F. \& DAWSON, G. W. P. - Episomic suppression of phenotype in Salmonella. Genet. Res. (Camb.) 5:169, 1964.

19. TAKAHASHI, T. - Filtration methods for selecting auxotrophic mutants of flocculent type yeast. Report Kihare Inst. Biol. Res. 10: $249,1959$.

20. WACHSMAN, J. T. \& HOGG, L. - Use of 5-fluorouracil for the isolation of auxotrophic mutants of Bacillus megaterium. J. Bact. 87: $1137-9,1964$.

21. WACHSMAN, J. T. \& MANGALO, R. - Use of 8-azaguanine for the isolation of auxotrophic mutants of Bacillus megaterium. J. Bact. 83: $35-7,1962$. 